\title{
Positive relationship between citrus leaf miner and alternaria brown spot
}

\section{Correlação positiva entre lagarta-minadora-dos-citros e mancha marrom de alternária}

\author{
Fernando Alves de Azevedo ${ }^{I^{*} \text {, II }}$ Ivan Bortolato Martelli ${ }^{\mathrm{I}}$ II Denis Augusto Polydoro \\ Camilla de Andrade Pacheco ${ }^{\mathrm{I}, \text { II }}$ Evandro Henrique Schinor ${ }^{\mathrm{I}}$ Marinês Bastianel $^{\mathrm{I}}$
}

\section{- NOTE -}

\section{ABSTRACT}

Alternaria brown spot, or ABS (Alternaria alternata), is the most prevalent fungal disease of tangerines in the world. Field observations have revealed ABS lesions on leaves wounded by the citrus leaf miner (CLM). Thus, the objective of this study was to assess the relationship between CLM and ABS. Leaves from young Murcott tangor plants and detached leaves from 16 different varieties of tangerines with and without lesions caused by CLM were inoculated with $A$. alternata. The symptoms of the plants were subsequently quantified by counting the number of lesions, and the lesion area was estimated using a diagrammatic scale. The presence of CLM damage aggravates the severity of Alternaria alternata fungus infections in susceptible tangerine varieties.

Key words: Alternaria alternata, Phyllocnistis citrella, tangerine.

\section{RESUMO}

A mancha marrom de altenária, ou MMA (Alternaria alternata), é a doença fúngica mais importante das tangerinas no mundo. Observações de campo revelaram a ocorrência de lesões de MMA em folhas feridas pela lagarta-minador-dos-citros (LMC). Assim, o objetivo deste estudo foi avaliar a relação entre a LMC e MMA. Folhas jovens de plantas de tangor Murcott e folhas destacadas de 16 diferentes variedades de tangerinas com e sem lesões, causadas por CLM, foram inoculadas com A. alternata. Os sintomas da MMA foram subsequentemente quantificados através da contagem do número de lesões, e a área da lesão foi estimada utilizando uma escala diagramática. A presença de danos da LMC agrava a severidade de Alternaria alternata nas variedades de tangerina suscetiveis.

Palavras-chave: Alternaria alternata, Phyllocnistis citrella, tangerine.
Alternaria brown spot (ABS), induced by Alternaria alternata, is the principal fungal disease of tangerines and occurs in most citrus-producing countries. The symptoms of ABS are small black or brown spots on young leaves and small lesions with a corky appearance, with or without a chlorotic halo, which occur on the twigs and fruits (AKIMITSU et al., 2003).

Field observations in susceptible varieties (Ponkan and Murcott), show that ABS symptoms are worse in the presence of wounds caused by the citrus leaf miner (CLM; Phyllocnistis citrella Stainton). The tunnels formed due to $\boldsymbol{P}$. citrella feeding have a secondary effect: they serve as an entry point for opportunistic pathogens, such as Xanthomonas citri subsp. citri, the causal agent of citrus canker. The relationship between $\boldsymbol{P}$. citrella and $\boldsymbol{X}$. citri has been described (JESUS JUNIOR et al., 2006). However, there are no studies indicating a relationship between ABS and CLM larvae.

In the first trial, two treatments were tested in two-year-old Murcott tangor plants: 1. CLM control; 2. CLM damage. In treatment 1, the insecticide Actara 250 WG (thiamethoxam) was applied ( $1.5 \mathrm{~g}$ seedling $\left.{ }^{-1}\right)$ to CLM control. When CLM lesions were observed on the plants of treatment 2 , they were inoculated with a suspension containing A. alternata conidia $\left(10^{5}\right.$ conidia $\left.\mathrm{mL}^{-1}\right)$, using $10 \mathrm{~mL}$ of suspension plant ${ }^{-1}$. Each plant was kept in a wet chamber for 48 hours. The severity of A. alternata

'Centro de Citricultura Sylvio Moreira, Instituto Agronômico, CP 04, 13490-970, Cordeirópolis, SP, Brasil. E-mail: fernando@centrodecitricultura.br. "Corresponding author.

IIPós-graduação em Agricultura Tropical e Subtropical, Instituto Agronômico, Campinas, SP, Brasil. 
infection was evaluated 96 hours after inoculation by analyzing three young leaves in each plant, according to a diagrammatic scale developed by MARTELLI (2011). Two trials were conducted under a completely randomized study design and ten replicates during the years 2009 and 2010 (replicate).

During a second trial, initially, eight tangerine resistant varieties (Cravo, Fremont, Murcott Irradiada, Nules, Satsuma Okitsu, Satsuma Owari, Ortanique and Thomas) and eight susceptible varieties (Table 1) were selected. Ten plants from each genotype were used. Thiamethoxam $(1.5 \mathrm{~g}$ plant $^{-1}$ ) was applied to half of them, which ensured that this material would be free from CLM galleries. Young leaves $(3-4 \mathrm{~cm})$ were picked from the canopy of plants and were washed in water, dried at room temperature and placed in Petri dishes containing a layer of filter paper and a small amount of wet cotton cloth. A. alternata inoculation was performed a spray containing a conidial suspension $\left(10^{5}\right.$ conidia $\mathrm{mL}^{-1}$ ) using $1.0 \mathrm{~mL}$ leaf ${ }^{-1}$. The material was kept in an incubator chamber $\left(27^{\circ} \mathrm{C}, 12\right.$-hour photoperiod, $96 \%$ relative humidity). The experiment was conducted under a completely randomized design in a $16 \times 2$ factorial scheme, with four replicates. The experiment was performed in 2010 and repeated in 2011. Evaluations were conducted between 72 and 96 hours after inoculation by observing the number of lesions and the percentage of the total area injured by disease (scale trial 1). The mean values obtained in the two trials were subjected to an analysis of variance and subsequent comparison of means (Tukey, $\mathrm{P} \leq 0.05$ ). The year was considered a factor to analyze.
The severity of ABS was increased in plants with leaf injuries caused by CLM (Figure 1). There was no difference between the evaluated years. Hence, there is a relationship between CLM and ABS in susceptible varieties such as Murcott tangor. Although the predisposition effect of leaf miners on the increment of Alternaria spot disease was previously published for tomato (DURAIRAJ et al., 2010) but there are no published data with tangerine. The mechanism of action of neonicotinoid insecticides as inducers of disease resistance in plants is still unclear. Shown promising results in controlling citrus canker (FRANCIS et al., 2009), but did not affect germination, vegetative growth and pathogenicity of fungi (NEVES et al., 2001).

The severity of $\boldsymbol{A}$. alternata in susceptible varieties of tangerines is increased in the simultaneous presence of damage caused by CLM and ABS conidia (Table 1 and Figure 2). Resistant varieties are not affected by ABS, even under conditions involving tissue injury (data not shown), this finding confirms the resistance of these genotypes described in other studies (PACHECO et al., 2012). One important aspect of these findings is related to the mechanism of Alternaria alternata attack and host defense. There is a consensus in the literature that any injury to plant tissue serves as an entry point for pathogens. This finding was not confirmed in the resistant varieties evaluated in the present study; it was only confirmed in susceptible varieties. These data suggest that resistant tangerine genotypes do not depend on physical mechanisms to prevent the development of this disease and that the underlying response

Table 1 - Average number of lesions and severity of Alternaria alternata in leaves from different tangerine genotypes in the presence (CLM damage) and absence (CLM control) of citrus leaf miner lesions (2010 and 2011).

\begin{tabular}{|c|c|c|c|c|}
\hline \multirow{2}{*}{ Variety } & \multicolumn{4}{|c|}{------------------Number of lesions*---------------- --------------------------Severity $\left(\%{ }^{* *}\right.$} \\
\hline & CLM damage & CLM control & CLM damage & CLM control \\
\hline Dancy & $51.0 \mathrm{Aa}^{1}$ & $37.5 \mathrm{ABa}$ & $100.0 \mathrm{Aa}$ & $44.3 \mathrm{Ab}$ \\
\hline Empress & $32.5 \mathrm{ABa}$ & $32.0 \mathrm{ABa}$ & $91.7 \mathrm{ABa}$ & $44.3 \mathrm{Ab}$ \\
\hline Dweet & $14.5 \mathrm{Ba}$ & $11.0 \mathrm{ABa}$ & $91.7 \mathrm{ABa}$ & $38.7 \mathrm{Ab}$ \\
\hline Sul da África & $36.5 \mathrm{Aba}$ & $17.5 \mathrm{ABb}$ & $83.3 \mathrm{AB}$ a & $44.3 \mathrm{Ab}$ \\
\hline Weshart & $17.0 \mathrm{Bb}$ & $42.0 \mathrm{Aa}$ & $75.0 \mathrm{ABCa}$ & $21.7 \mathrm{Ab}$ \\
\hline Ponkan & $38.0 \mathrm{ABa}$ & $14.0 \mathrm{ABb}$ & $61.0 \mathrm{BCa}$ & $24.3 \mathrm{Ab}$ \\
\hline Osceola & $35.5 \mathrm{ABa}$ & $4.5 \mathrm{Bb}$ & $58.3 \mathrm{BCa}$ & $30.3 \mathrm{Ab}$ \\
\hline África do Sul & $16.0 \mathrm{Ba}$ & $6.0 \mathrm{Bb}$ & $36.0 \mathrm{Ca}$ & $21.7 \mathrm{Ab}$ \\
\hline $\mathrm{CV}$ & \multicolumn{2}{|c|}{13.5} & \multicolumn{2}{|c|}{15.6} \\
\hline
\end{tabular}

${ }^{1}$ means followed by the same capital letter in the column and lower case letter in the row, for each evaluation hour, do not differ from each other (Tukey, $\mathrm{P}=0.05) ; * 72$ hours after inoculation; $* * 96$ hours after inoculation. $\mathrm{CV}=$ Coefficient of variation.

Ciência Rural, v.45, n.7, jul, 2015. 


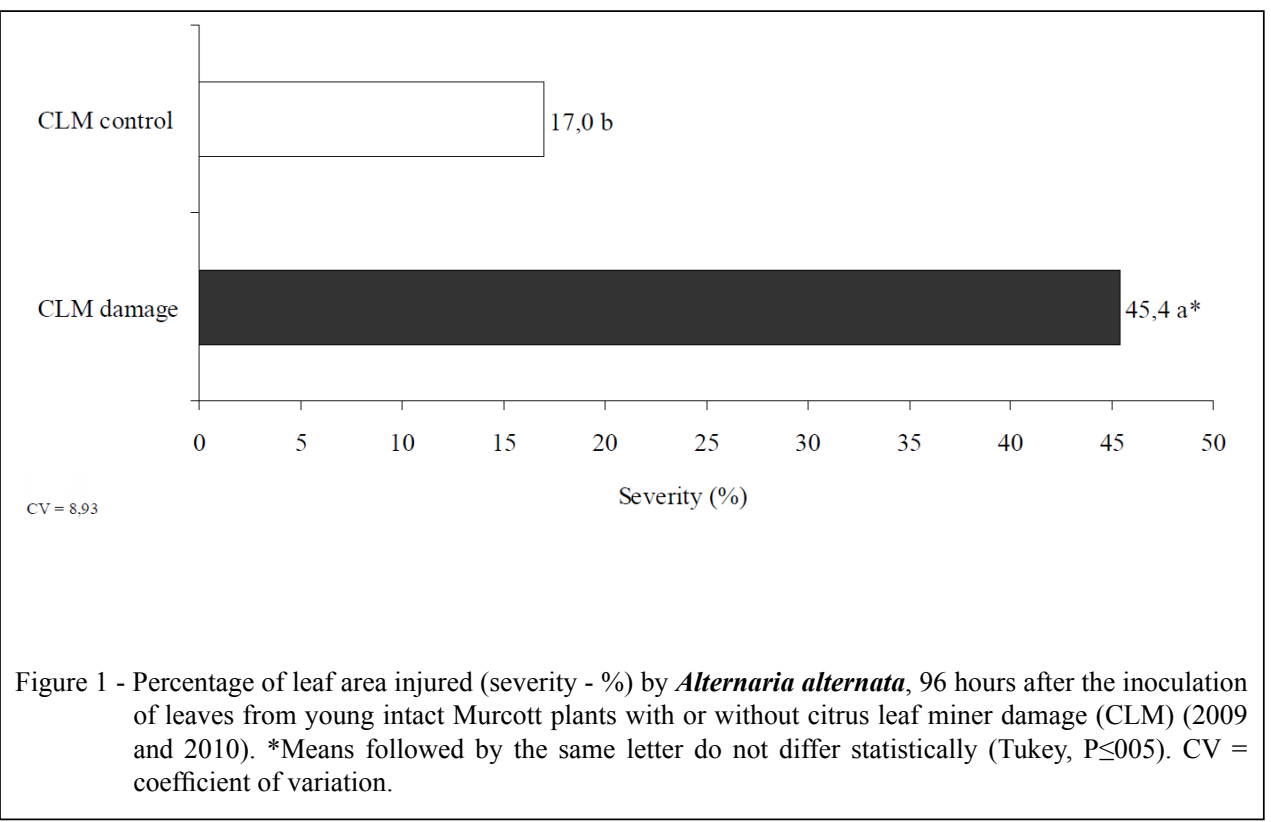

mechanism must be related to biochemical processes occurring at the time when the pathogen attempts to colonize the tissue (IAKIMOVA et al., 2006).

Little knowledge is available regarding the defense mechanisms of resistant tangerine varieties, and few publications have conclusively addressed this issue. It is known that the colonization process occurs as a consequence of antioxidant production by the pathogen, which nullifies the effects of molecules generated by plant peroxidases in the hypersensitivity response. Furthermore, high levels of peroxides in plant cells can induce programmed cell death (LIN

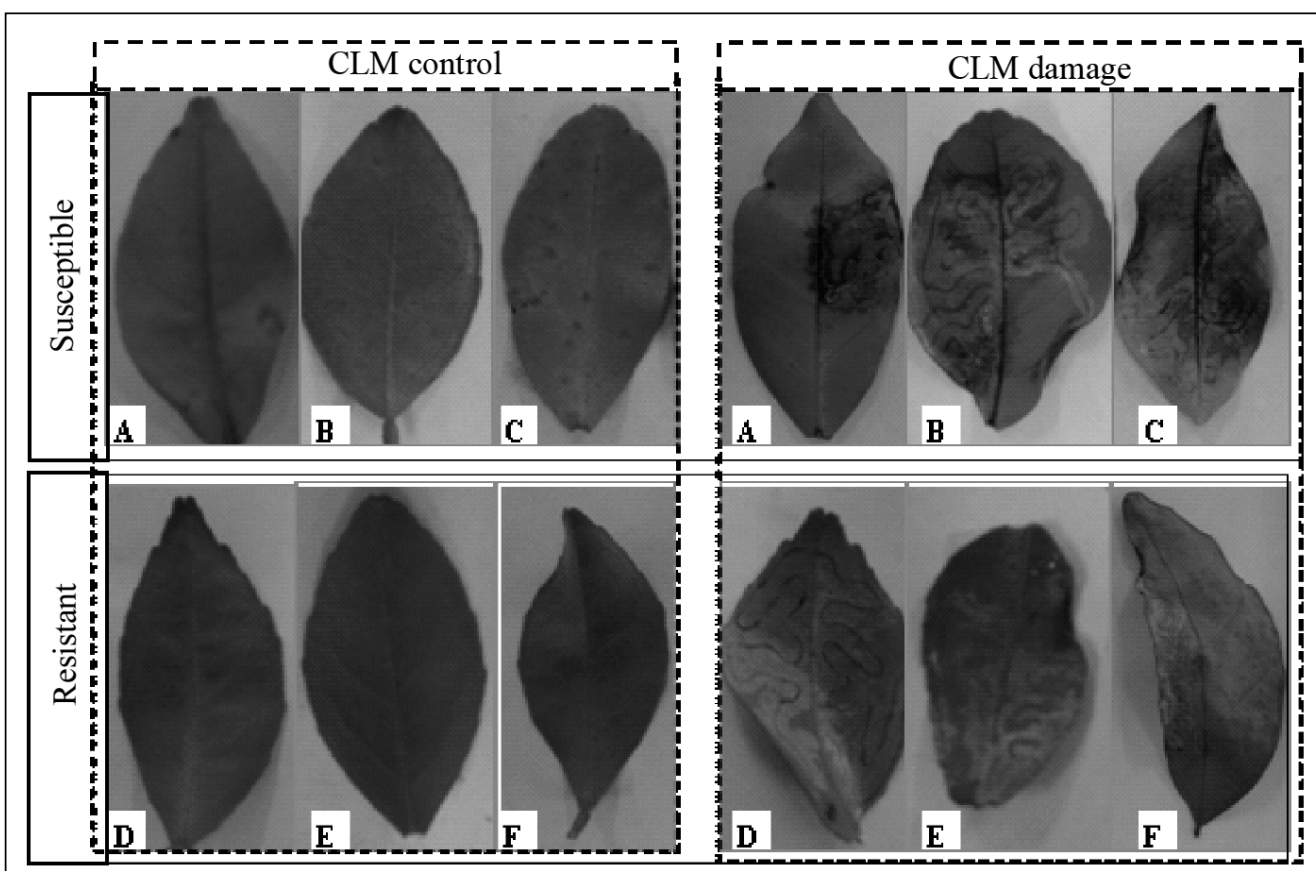

Figure 2 - Images of leaves from different tangerine genotypes in the absence (left) and presence (right) of citrus leaf miner (CLM) lesions following Alternaria alternata inoculation. A África do Sul; B Sul da África; C Weshart; D Thomas; E Cravo; F Ortanique. 
et al., 2011). STUART et al. (2009) suggested that A. alternata lesion occurs through penetration of the stomata. In tissues containing tunnels, the pathogen probably is succesful in enhancing its toxin, most likely because of the time when leaf transpiration reaches a peak, water accumulates inside the tunnels (as observed in the present study). In this situation, the toxin released by the pathogen may be related to oxidant production by cells contacting the toxin, thus resulting in a greater number of dead cells.

Planting brown spot-resistant varieties is an alternative that will decrease pesticide costs, as this characteristic is not affected by the presence of CLM. The results of these experiments are important and suggest that controlling CLM may help mandarin producers to confront alternaria brown spot. Tangerines growers should practice management strategies that emphasize both insect and disease control.

\section{ACKNOWLEDGEMENTS}

We thank Conselho Nacional de Desenvolvimento Científico e Tecnológico $(\mathrm{CNPq})$ for financial support of the project and for granting scholarships (Martelli, I.B, Polydoro, D.A., Pacheco, C.A., Bastianel, M. and Azevedo, F.A.).

\section{REFERENCES}

AKIMITSU, K. et al. Molecular, ecological and evolutionary approaches to undertanding Alternaria diseases of citrus. Molecular Plant Pathology, v.4, p.435-436, 2003. Available from: <http:// www.ncbi.nlm.nih.gov/pubmed/20569403>. Accessed: Jan. 20, 2014. doi: 10.1046/j.1364-3703.2003.00189.x.

DURAIRAJ, C. et al. Predisposion effect of Liriomyza trifolii damage to Alternaria leaf spot disease in tomato. Karnataka Journal of Agricultural Science, v.23, p.161-162, 2010.
FRANCIS, M.I. et al. Soil application of imidacloprid and related SAR-inducing compounds produces effective and persistent control of citrus canker. European Journal of Plant Pathology, v.22, p.283-292, 2009. Available from: <http://www.ingentaconnect. com/content/klu/ejpp/2009/00000124/00000002/00009415>. Accessed: Dec. 12, 2013. doi: 10.1007/s10658-008-9415-x.

IAKIMOVA, E.T.et al. Hypersensitive cell death in plants - its mechanisms and role in plant defence against pathogens. Journal of Fruit and Ornamental Plant Research, v.13, p.134-158, 2006.

JESUS JUNIOR, W.C. et al. Injúrias da larva minadora dos citros (Phyllocnistis citrella) intensificam a infecção por cancro cítrico (Xanthomonas axonopodis pv citri). Fitopatologia Brasileira, v.31, p.277283, 2006. Available from: <http://www.scielo.br/pdf/fb/v31n3/a06v31n3. pdf $>$. Accessed: Dec. 12, 2013. doi: 10.1590/S0100-41582006000300006.

LIN, C.H. et al. Cellular responses required for oxidative stress tolerance; colonization; and lesion formation by necrotrophic fungus Alternaria alternata in citrus. Current Microbiology, v.62, p.807815, 2011. <http://link.springer.com/article/10.1007/s00284-0109795-y>. Accessed: Dec. 12, 2013. doi: 10.1007/s00284-010-9795-y.

MARTELLI, I.B. Manejo de mancha marrom de alternária em citros: poda de limpeza e correlação com lagarta minadora. 2011. 41f. Dissertação (Mestrado em Agricultura Tropical e Subtropical) - Curso de Pós-graduação em Agricultura Tropical e Subtropical, Instituto Agronômico, Campinas/SP.

NEVES, P.M.O.J. et al. Compatibility of entomopathogenic fungi with neonicotinoids insecticides. Neotropical Entomology, v.30, p.263-268, 2001. Available from: <http://www.scielo.br/pdf/ne/ v30n2/a09v30n2.pdf>. Accessed: Dec. 12, 2013. doi: 10.1590/ S1519-566X2001000200009.

PACHECO, C.A. et al. Resistance and susceptibility of mandarins and their hybrids to Alternaria alternata. Scientia Agricola, v.69, p.347-403, 2012. <http://ainfo.cnptia.embrapa.br/digital/ bitstream/item/68179/1/Beatriz-2012.pdf $>$. Accessed: Jan. 05, 2014. doi: 10.1590/S0103-90162012000600007.

STUART, R.M. et al. Alternaria brown spot. Laranja, v.30, p.29-44, 2009. 